\title{
NEW ESSAYS ON JOHN CLARE \\ Poetry, Culture and Community
}

\author{
Edited By \\ SIMON KÖVESI \\ Oxford Brookes University \\ and \\ SCOTT MCEATHRON \\ Southern Illinois University
}




\section{CAMBRIDGE UNIVERSITY PRESS}

University Printing House, Cambridge св2 8вs, United Kingdom

Cambridge University Press is part of the University of Cambridge.

It furthers the University's mission by disseminating knowledge in the pursuit of education, learning and research at the highest international levels of excellence.

$$
\text { www.cambridge.org }
$$

Information on this title: www.cambridge.org/978II0703IIII

$$
\text { (C) Cambridge University Press 2015 }
$$

This publication is in copyright. Subject to statutory exception and to the provisions of relevant collective licensing agreements, no reproduction of any part may take place without the written permission of Cambridge University Press.

First published 2015

Printed in the United Kingdom by XXXXXXXXXXXXXXX

A catalogue record for this publication is available from the British Library

\section{Library of Congress Cataloguing in Publication data}

New essays on John Clare : poetry, culture and community / edited by Simon Kövesi and Scott McEathron.

$$
\text { pages } \mathrm{cm}
$$

Includes bibliographical references and index. ISBN 978-I-IO7-O3III-I (hardback)

I. Clare, John, I793-I864-Criticism and interpretation. I. Kövesi, Simon, editor. II. McEathron, Scott, I962- editor.

$$
\begin{gathered}
\text { PR4453.c6Z84 20I5 } \\
82 \mathrm{I}^{\prime} \cdot 7-\mathrm{dc} 23 \\
201500828 \mathrm{I}
\end{gathered}
$$

ISBN 978-I-IO7-03III-I Hardback

Cambridge University Press has no responsibility for the persistence or accuracy of URLs for external or third-party internet websites referred to in this publication, and does not guarantee that any content on such websites is, or will remain, accurate or appropriate. 


\section{Contents}

Notes on contributors page vii

Acknowledgements

$\mathrm{x}$

List of abbreviations

Introduction

Simon Kövesi and Scott McEathron

PART I：POETRY

I John Clare's colours

Fiona Stafford

2 John Clare, William Cowper, and the eighteenth century Adam Rounce

3 John Clare's conspiracy

Sarah M. Zimmerman

PART II：CULTURE

4 John Clare and the new varieties of enclosure: a polemic John Burnside

5 Ecology with religion: kinship in John Clare Emma Mason

II8

6 The lives of Frederick Martin and the first Life of John Clare Scott McEathron

7 John Clare's deaths: poverty, education, and poetry 146 Simon Kövesi 
vi

Contents

PART III: COMMUNITY

8 John Clare's natural history

I69 Robert Heyes

9 'This is radical slang': John Clare, Admiral Lord John Radstock, and the Queen Caroline affair Sam Ward

Select bibliography 
CHAPTER 2

\section{John Clare, William Cowper, and the eighteenth century}

Adam Rounce

When Francis Palgrave included William Cowper's 'The Poplar-Field' (1785), in his I86I anthology the Golden Treasury, he had Tennyson's approval: according to Palgrave's manuscript notes the Laureate 'especially admired its sweet flow - said he did not know why, but it seemed as if no such verses could be written now.' This suggestive sentiment - an expression of nostalgic regret for the lost possibilities of a poetry of nostalgia - serves to remind the reader of how English poetry had changed during the lifetime of John Clare. Clare, who would die three years later, was born less than ten years after Cowper had lamented the loss of the eponymous poplars, where 'the tree is my seat that once lent me a shade', in the sort of poem - wistful, full of generalized sentiments and euphony which would help make Palgrave's enterprise so successful. It is the sort of lament that seems to connect intimately to Clare's own poetry and his aesthetic, with its melancholy detailing of rural despoliation and its consequences. Clare's reverence for Cowper is well-documented, yet this connection is also marked by a disjunction: Tennyson sagely noted that the 'sweet flow' of Cowper's lines seems to make them belong immutably to the past, and would simply not be possible to write in the world of the mid-nineteenth century. Much of Clare's poetry follows the same pattern as that of Cowper and other eighteenth-century forebears (such as James Beattie and Oliver Goldsmith), but then veers off into its own very specific territory. It is the point of the present chapter to describe this movement by Clare from sympathetic identification with, and near emulation of, Cowper, to a clearly defined, sometimes apparently slight - but always precise - distinction from him. The general premise will be to indicate the degree of empathy between Clare and eighteenth-century poetry, to show how much he absorbs from this poetic tradition, and what he adds to it. It is useful to start with a brief consideration of the general influence of eighteenth-century poetry upon Clare, with specific reference to the example of James Thomson. 
The relationship between Clare and the poetry of the eighteenth century has become, in some ways, an established part of the narrative of his career, from the sentimental anecdote (the inspirational discovery of Thomson's Seasons) to more recent critical attention to the connection with and dissonance between Clare and his forebears in the poetry of pastoral landscape (in the work of John Barrell and others). It is inevitable, of course, that the large-scale recovery of Clare's poetry in the last half-century has created various conflicting readings of his place in any poetic narrative of the eighteenth century and Romanticism. This is, doubtless, partly the result of narratives of literary history and their often procrustean needs, but also a reflection of some cogent qualities in Clare's large poetic canon: specifically, his fecundity, and his mode of composition in a variety of forms and genres. In a related vein, Clare often composed poetry close to his forebears in a spirit of pastiche, or homage, or a mixture of the two (the use of Beattie in the Spenserian 'Village Minstrel' and the much later asylum parodies of Don Juan and 'Childe Harolde' are notable examples). The result is a poetry that manages to borrow from, imitate, acknowledge the weight of, and also transcend its eighteenth-century influences. Or, to use Bridget Keegan's summary, the

heteroglossic nature of Clare's poetry both invites and precludes his comparison with and assimilation into a variety of literary idioms, ranging from that of the late eighteenth century loco-descriptive poets, to that of his Romantic contemporaries (in particular, Wordsworth), to that of the natural historians. ${ }^{2}$

Clare is thus impossible to pin down, as he shows so many influences as to resist identification with any one poetic movement or moment, defying any easy placing of him within a tradition.

What can be shown, though, are the ways in which Clare borrows elements from the literary past, including Thomson's Miltonic recreations of landscape and Cowper's meditative poems and lyrics of the later eighteenth century, in order to encompass a mindset that is increasingly beleaguered in its relations with the world. Clare especially shares with Cowper an interest in the revaluation and reshaping of traditional lyric forms.

Clare's relation to the eighteenth century has been a matter of some critical dispute, partly because it has been assumed to be part of a literary historiographic model whereby Romanticism frees itself from poetic predecessors; alternately, Clare has been held up as an example of veneration of the past at the expense of the present. A leading figure in this dispute is 
Clare's first poetic idol, James Thomson. As has often been discussed, Thomson's influence on Clare was always obvious, and John Taylor broadcast it in the 'Introduction' to his first published volume: 'He was thirteen years of age when another boy shewed him Thomson's Seasons. They were out in the fields together, and during the day Clare had a good opportunity of looking at the book. It called forth all the passion of his soul for poetry. ${ }^{\prime 3}$ This discovery is repeatedly seen as an epiphany - albeit one that was as much a marketing device as a statement of poetic inspiration - in its representation of Clare as follower of an established model.

John Barrell's reading of Clare and Thomson sees the latter as a model from which Clare had to extricate himself. Barrell emphasizes the difficulties of what landscape Clare as a subject could freely visualize and explore imaginatively. For Barrell, Thomson was therefore an influence that had to be shaken off: Clare's mature poems were

written as a deliberate and a considered alternative to the style of landscape description he had encountered in Thomson and other eighteenth-century descriptive poems. In his earliest books of poetry, Clare had made a number of more or less successful attempts to write in the mode of Thomson, but had turned away from these attempts, because he decided that Thomson's descriptive procedures could not be used to represent his own sense of place, his own consciousness, and the mutually constitutive relations of the two. ${ }^{4}$

The problem with this line of argument is that, retrospectively, Clare's departure from Thomson's style can be more of a natural lessening of influence in proportion to Clare's own poetic development and needs: it is possible to argue that Thomson's 'descriptive procedures' did not suit Clare for a number of reasons (particularity versus the general, for one). The counter-argument to claims of Clare writing himself away from the eighteenth century - suggesting instead a poetics of veneration - is offered by James McKusick, in accounting for the lack of congruence between Clare and his most famous contemporary:

Far more important than the Wordsworthian influence on Clare, especially in his early career, was his affectionate imitation of the poets of Sensibility: Thomson (whose The Seasons was the first book of poetry that Clare ever possessed), Cowper (whose fondness for small defenceless creatures especially appealed to Clare), Gray and Collins. Clare admired these poets not because they were (or once had been) fashionable, but because for him they constituted an alternative poetic tradition, one that exalted the rural landscape and the rural sense of community over the anomie of urban existence. ${ }^{5}$ 
This genial model of influence, in turn, does not question the extent of Clare's affection. It risks over-determining the poetry of urban anomie (which would hardly be recognized by Clare as a distinct body of work), and simplifying the diversity of Gray, Collins, and the rest: after all, Collins's highly allegorical and obscure odes do not replicate Gray's Elegy in exalting the rural landscape and community (if, indeed, that is what Gray's famous poem does).

It is possible to see both sides, and accommodate Clare's poetic requirements within the benefits and limitations of past influences. In a practical sense, Clare did follow Thomson, like most other writers of topographical poetry, whilst moving away from his example in tangible and almost tactile ways. As a reminder of what Clare was responding to, it is worth looking back a passage from Winter (1726), in which Thomson's description of the arrival of snow suggests earthly uncertainty:

Earth's universal Face, deep-hid, and chill, Is one wild dazzling Waste, that buries wide The Works of Man. The Labourer-Ox Stands cover'd o'er with Snow, and then demands The Fruit of all his Toil. The Fowls of Heaven, Tam'd by the cruel Season, croud around The winnowing Store, and claim the little Boon, Which Providence allows. ${ }^{6}$

Thomson's verse is built around following the strikingly universal impulse with the particular; the obvious qualities that mark this passage as being of the first part of the eighteenth century are both the diction and constructions - the descriptive register that includes the 'Labourer-Ox' and the King James Version's 'Fowls of Heaven' - though the 'winnowing Store', ostensibly an example of the sort of ornate diction that would become notorious for its superfluity, is simply describing the process of sorting the wheat. Clare's poetic perspective is often described as inherently more localized, and therefore naturally less abstract and removed than such a landscape tradition; his writings in this vein do not seem ostensibly different, but in the level of their detail the change becomes apparent, as in an I820s piece such as 'Snow Storm':

What a night the wind howls hisses \& but stops

To howl more loud while the snow volley keeps

Incessant batter at the window pane

Making our comfort feel as sweet again

$\&$ in the morning when the tempest drops

At every cottage door mountainous heaps 
Of snow lies drifted that all entrance stops

Untill the beesom \& the shovel gain

The path - \& leave a wall on either side -

The shepherd rambling valleys white $\&$ wide

With new sensations his old memory fills

When hedges left at night no more descried

Are turned to one white sweep of curving hills

And trees turned bushes half their bodys hide.

(lines 1-14; Middle Period, V, 213)

The onrushing of sensory impression here and the concomitant accumulation of effects and sensations is, alongside the enjambed, unpunctuated lines, the most significant alteration from Thomson's method of description. Paul Chirico captures the feeling of these lines in referring to their 'visual intensity' and method of description which 'is defamiliarising, even uncanny', part of his larger argument that 'Although Clare is usually described as a poet of place, of precise, localized natural description, his landscapes are in fact repeatedly transformed, their familiarity undermined by disorientation or by an excess of detail.' The problem, in some ways, is 'the troubled and unresolved relationship between precise, yet diverse and constantly changing, natural observations and their fixed and limited representation in poetry and memory. ${ }^{7}$ There is also, in this example, alongside Clare's customary reluctance towards blank verse, the anthropomorphic feel in the trees at the end, which leads to a sense of intimacy and informality, and a perspective that is both generalized and local in its range.

To say as much is to point out that Clare's uniquely off-kilter description, combined with the diction and tone that reflects his closeness to his subject-matter, means that he follows eighteenth-century poetic landscapes in outline, but makes them seem more familiar, domestic, intimate, and therefore empathetic in their details. He is not at odds with Thomson, but the latter was generally aiming for a poetic decorum that Clare found unsuitable, and not entirely reflective of the impression that he was trying to make. In this sense, there is a distance between them, in that the ingenuous informality and intimacy that Clare creates was not generically open to Thomson - and it was also not surprising that Thomson's mode of address in most of his poetry reflected the manners of a bygone age, and therefore was not available to Clare, even had he wished to avail himself of it. Thomson was not a shadow from which Clare had to extricate himself, but part of a tradition that was open to him to a certain extent. 
What is needed, perhaps, is a via media between general perceptions of Clare's recent poetic past as ultimately either oppressive or sympathetic. John Goodridge has recently challenged the 'common critical view' which holds the eighteenth-century influence on Clare to be 'a slightly embarrassing literary adolescence through which he must pass to find his own authentic voice', offering instead 'more positive aspects' of such influence, and viewing Clare's relations with the past as not a 'restraining or intimidating presence' upon him, but rather 'a new door to open'. 8

Goodridge disputes the bald idea that Clare moved from hackneyed and commonplace copying of the eighteenth century to find simplicity and the natural in his own environment and style. He instead offers influential texts and paratexts as examples of where the eighteenth century made a direct, detailed contribution towards Clare's poetic apprenticeship. John Pomfret's 'The Choice' ( 1700 ) - that hugely popular Horatian message of desired retirement and ease - lies behind Clare's early 'wish' poems. Along with the debts to Goldsmith and Beattie, ${ }^{9}$ Goodridge also identifies the once-widely read pastorals of John Cunningham as a positive source for Clare's own writing, helping him to absorb the octosyllabic line (as did John Dyer's 'Grongar Hill', I756). Goodridge also presents Gray's Elegy as a sort of ur-text for Clare's attempts throughout his career to understand the fate of the labouring-class writer. ${ }^{\text {IO }}$ For Goodridge, 'a key challenge in Clare's literary development was that of accommodating in his style both the "high" literary culture to which he aspired, and the rich narratives and songs of folk and popular culture with which he had grown up." Goodridge's laudable general aim is to represent, where possible, the specific details of comparison and contrast between Clare and his 'high' predecessors. The following readings of Clare's interactions with Cowper (and by implication, as least some of the eighteenth-century poetic past) will try to emulate this spirit of detailed enquiry.

\section{II}

For all Thomson's general influence, especially early in Clare's career, there are fewer shared factors between the two poets than are common in Clare and the later William Cowper, a poet whose range of styles and characteristic themes reflect Clare's own restless generic and formal invention. The closeness of Clare and Cowper has been touched upon many times: Clare himself addressed lines to 'Cowper the Poet of the field', and while the more genteel Cowper had a slightly different experience of a field, the biographical points of similarity between the two are hard to gainsay: apart 
from their mental difficulties, both fell back upon and wrote about solitude, retirement, and isolation from a community. Cowper's was chosen, a result of mental difficulties and a near-paranoid sense of religious guilt; Clare's was enforced, given his repeated levels of conflict with and antipathy towards many in his community, at certain stages of his life. ${ }^{\text {I2 }}$

Clare's attitude towards Cowper was always plain. On his trip to Huntington in March 1820 en route to his first visit to London, he was shown Cromwell's house, as well as 'the parsonage with its mellancholy looking garden', Cowper's former residence, 'which was far the most interesting remembrance to me tho both were great men in the annals of fame'. ${ }^{\text {I3 }}$ In terms of poetry, the appeal of Cowper to Clare as a model would encompass rather darker and more troubled areas, but it could well have originated in the (relative) informality of The Task, that long meditation on everything and anything that, like so much of Clare's work, is rooted in the associations, values, and feelings of landscape, and the relaxed mood of the conversation poem. In this respect, one cogent area of comparison between the two poets is the shared sense of the pleasures of sometimes necessary retirement from the noise and follies of the world: in the asylum period, in the 'Lines on Cowper', Clare refers to the reading of books five and six of The Task: "The "Winters walk" and "Summers Noon" / We meet together by the fire' (lines 17-18; Later Poems, II, 87I). This joy in retirement is also shown in the poets' respective descriptions of winter, where the pleasure of reading is a compensation for necessary confinement. Cowper apostrophizes the season thus:

I crown thee King of intimate delights, Fireside enjoyments, home-born happiness, And all the comforts that the lowly roof Of undisturb'd retirement, and the hours Of long uninterrupted evening know. ${ }^{\text {I4 }}$

It is this sense of intimacy that retirement gives which Clare also captures in another late piece, 'The Winters Come', when describing the relish and passion for reading, and the implicit release from the cares of the world that the season enables:

'Tis Winter, and I love to read in-doors,

When the moon hangs her crescent upon high:

While on the window shutters the wind roars,

And storms like furies pass remorseless by,

How pleasant on a feather bed to lie,

Or, sitting by the fire, in fancy soar 
With Milton, or with Dante to regions high, Or read fresh volumes we've not seen before, Or o'er old Barton's 'melancholy' pore.

(lines 19-27; Later Poems, II, 929)

The register is slightly more informal, and the bookish delight a childish pleasure at the familiarity of the well-worn and the new. It is also a reminder of Clare's relish of the world of the bookish retreat: as Richard Cronin has suggested, Clare, more often than his contemporaries, 'presents himself in his poems as a reader, as a man who when he returns home from a walk' picks a book from the shelves. ${ }^{15}$ The idiomatic spelling of Robert Burton aside (like Samuel Johnson, Clare apparently appreciated The Anatomy of Melancholy as one of the great books to dip into), the sublimity of Milton is accompanied by Dante, whose reception in English was in its relative infancy. ${ }^{16}$ The jarring metre of the line, however, is odd given Clare's perfect ear for scansion, and it is possible he did not intend 'Dante' to be pronounced with more than one syllable. Yet the passage shares with Cowper a paramount sense of the joy of the solitary experience - of the season as a fortunate excuse for the natural retreat towards books and the fire by certain temperaments.

Such temperaments are drawn to the meditative, and this is why Cowper, a poet of profound levels of introspection (albeit leading him to estrangement and alienation), is a helpful prism through which to view Clare, not least in considering how close Clare is to Cowper's style, and how clearly he moves away from it. To stay with the descriptive powers of both on the subject of winter, Cowper is appropriately more grounded in an eighteenth-century blank verse tradition:

Forth goes the woodman leaving unconcerned

The cheerfull haunts of man, to wield the axe

And drive the wedge in yonder forest drear,

From morn to eve his solitary task.

Shaggy and lean and shrew'd, with pointed ears

And tail cropp'd short, half lurcher and half cur

His dog attends him. Close behind his heel

Now creeps he slow, and now with many a frisk

Wide-scampering snatches up the drifted snow

With iv'ry teeth, or ploughs it with his snout;

Then shakes his powder'd coat and barks for joy. ${ }^{17}$

What is so marked here is the level of detail that Cowper is striving towards, expressed, inevitably, through the Latinate syntax that he would pursue in most of his mature blank verse, as a conscious homage to Milton, 
and which would lead to his Homer translations. Here, this explains the allusion to the fall of Mulciber, the architect of Pandemonium in Paradise Lost, in 'from morn to eve'. ${ }^{8}$ Although this is thirty-five years before Clare's first publications, despite the syntactic constructions and the somewhat ornate diction ('frisk', 'ivory', and 'powder'd coat') Cowper is after the sort of detail that Clare would later delineate. Clare's own descriptions are in a similar if somewhat less formal register. Take the asylum sonnet from the Epping forest period (mainly, and rarely for Clare in this period, in blank verse), 'Gipsy Camp':

THE snow falls deep; the Forest lies alone:

The boy goes hasty for his load of brakes,

Then thinks upon the fire and hurries back;

The Gipsy knocks his hands and tucks them up,

And seeks his squalid camp, half hid in snow,

Beneath the oak, which breaks away the wind,

And bushes close, with snow like hovel warm:

There stinking mutton roasts upon the coals,

And the half-roasted dog squats close and rubs,

Then feels the heat too strong and goes aloof;

He watches well, but none a bit can spare,

And vainly waits the morsel thrown away:

'Tis thus they live - a picture to the place;

A quiet, pilfering, unprotected race.

(Later Poems, I, 29) ${ }^{19}$

The final 'unprotected', with its support for the underdog and compassionate reaching for the margins of society, could come from few, if any other poets of the period, or the preceding century. It is the only point of judgment; hence, it stands apart from the near-documentary realism of the poem. Alan Vardy has described the poem as a 'realistic delineation of a series of moments' that nonetheless acts as a profound kind of 'imaginative sympathy' with its marginalized subjects. Vardy continues:

Not only is Clare not interested in judging the gypsies, the only language of judgment is directed back at the reader as a challenge to his or her habitual notions about gypsies. The fact of their 'pilfering' is not denied, but rather is presented in the context of the description of the camp, and the other descriptive adjectives that surround it. ${ }^{20}$

The apparent neutrality of landscape description (more honoured in the breach anyway) is reframed as a test of the reader's prejudices; the three adjectives of the final line can act as a goad, a gently provocative defence of the downtrodden, and a sharply impressionistic and repeated focus on the gritty detail of the sort of lifestyles dismissed by sweeping judgment. It is in 
John Clare, William Cowper, and the eighteenth century

small, radical details such as this that Clare defined his own poetic space, akin to, but slightly at a remove from, Cowper: both poets are willing to represent and sympathize with the outcast and the marginal, but Clare's perspective on such figures tends to challenge the reader's preconceptions.

\section{III}

For all that the naturalism of Clare's gipsy-camp is more visceral than any realistic external landscape described by Cowper, the comparison between the two poets remains fruitful. Both identified with the destruction of the solidity of natural scenes, places, and objects as a metonym of wider attacks upon the communal and the individual by specific parts of modernity. For each poet, this resulted in an upheaval both of the quotidian and - more profoundly for the individual - of the existential surety that such venerated places represented. Here, too, Clare diverges from Cowper in important ways.

Cowper's attitude towards rural despoliation is summarized by Tim Fulford, recounting Cowper's response to one such action, the removal of what he called the Spinney:

In July 1785 a local landowner felled trees, removed scrub, and re-organized as an orderly plantation a wood near Olney through which had run one of Cowper's favourite walks. He mourned for its loss in terms that make of the picturesque glade a sanctuary of spiritual community shared between Cowper and his domestic circle:

I have promised myself that I will never enter it again. We have both pray'd in it. You for me, and I for you, but it is desecrated from this time forth, and the voice of pray'r will be heard in it no more.

Fulford concludes that, as the quoted letter implies, for Cowper, 'Rural beauty ... is sacramental, an earthly form in which spiritual presence can be encountered. Despoliation of nature is made to seem sacrilegious. And despoliation also threatens the self. ${ }^{2 I}$ These threats would never be negated, and would be expressed through the spiritually tortured poems that Cowper wrote, especially in the I790s, from 'On the Receipt of my Mother's Picture out of Norfolk' to 'The Castaway'. Yet, for all the genuine torment of these works, the automatic link between the destruction of the trees as a blasphemy and act of sacrilege in Cowper's letter here seems on one level a melodramatic, almost self-parodic expression of a particular kind of dissenting excess. The destruction of the solace of the walk for Cowper and his spiritual community may have been disappointing, but such a violation does not, arguably, possess the wider symbolic 
consequences that he suggests; he elevates an act of vandalism to a desecration perpetuated by the heathen.

This strange perspective is muted and transformed, beautifully, in 'The Poplar-Field', written late in 1783 and published in 1785 , in response to the felling of the trees in a familiar field next to the river Ouse in nearby Lavendon. The musicality of the anapaests may derive from its being designed as a setting for the favourite tunes of Cowper's friend Lady Austen. ${ }^{22}$ The content is formed around the conventional themes of the vanity of human wishes, and vitae summa brevis:

The black-bird has fled to another retreat

Where the hazels afford him a screen from the heat, And the scene where his melody charm'd me before, Resounds with his sweet-flowing ditty no more.

My fugitive years are all hasting away, And I must e'er long lie as lowly as they, With a turf on my breast and a stone at my head E'er another such grove shall arise in its stead.

'Tis a sight to engage me, if any thing can, To muse on the perishing pleasures of man; Short-lived as we are, yet our pleasures, we see, Have a still shorter date, and die sooner than we. ${ }^{23}$

The defiance and outrage of Cowper's letter is here replaced by a fatalistic sensibility, rendered in a very subdued poetic key, whereby meditation and melancholy use the loss of the stability of the locale to conclude in sententiae, which crucially seems divorced from the putative loss of the poplars. The result is a sentimental nostalgia that is always universal (which is indeed the source of its strength and appeal) but is wistfully separated from the object of its original protest. Moreover, it appears to accept its premise - that life and its pleasures are as transitory and fallible as any natural site threatened by 'improvement' - without hope of any alternative, in a manner which could be described as complacent, or solipsistic.

To say as much is not to expect a poet as constitutionally melancholy (and for such deep-seated reasons) as Cowper to add a happy ending, but it brings into light the most important contrast between him and Clare. For Clare, the destruction of an almost spiritual sanctuary leads not to resignation, but to a more complex blend of loss and recompense. Clare conveys a quietly defiant sense of a natural order that cannot be obliterated and that offers connections even amidst seemingly alien milieux, as in the closing lines of 'The Flitting': 
John Clare, William Cowper, and the eighteenth century

$\&$ why - this 'shepherds purse' that grows

In this strange spot - In days gone bye

Grew in the little garden rows

Of my old home now left - And I

Feel what I never felt before

This weed an ancient neighbour here

$\&$ though I own the spot no more

Its every trifle makes it dear

The Ivy at the parlour end

The wood bine at the garden gate

Are all \& each affections friend

That rendered parting desolate

But times will change $\&$ friends must part

$\&$ nature still can make amends

Their memory lingers round the heart

Like life whose essence is its friends

Time looks on pomp with careless moods

Or killing apathys disdain

- So where old marble cities stood

Poor persecuted weeds remain

She feels a love for little things

That very few can feel beside

$\&$ still the grass eternal springs

Where castles stood \& grandeur died

(lines 193-216; Middle Period, III, 488-9)

The workings of time and nature, and their genial contempt for the pretensions of civilization, act as a corrective to nascent despair, binding the poet to the solace of the imagination and its empathetic understanding of the underlying natural order. Much of Cowper's later work is a spiritual autobiography with nature repeatedly visualized as the symbol of his guilt and perceived damnation, and even in the gentle rhythms of 'The PoplarField' he is denied consolation. Clare is never so bereft. The sweep of Time and Nature, vast though they are, still nurture the 'little things / That very few can feel'.

It is, in one sense, Clare's refusal to accept the limiting terms of alienation and persecution that moves him away from Cowper and makes him a poet of localized, individual protest, not content to simply bemoan his fate, or to generalize around and thereby mystify the conditions under which he has been alienated from his environment. With Cowper, whether or not this reflects his more detached relationship to the process of labour and the land, it is possible to find in his 
poetry meditations upon change, the ravages of time, and the shortcomings of human attempts to alter and control his environment; yet these usually lead to a symbolic debate, whereby it is Cowper's lasting lack of spiritual nourishment, and his perceived alienation from God's mercy, which is the latent source and the end of his writing. The result, often, is that the details of the landscape, object, or vista of his subject are individualized, or latently act out parts of his lasting spiritual dilemma.

An example of this is 'Yardley Oak' (I79I), the unfinished blank-verse meditation on history and the understanding of the past that is one of Cowper's most profound explorations of his place within the world of time and nature. The old tree of the title, a survivor, like the poet, of many past struggles, has lost much in the transition from youth to age. Yet the potentially uplifting pastoral salute to its endurance does not last. The very aspects of the tree that so fascinate the poet - its longevity in the face of adversity, its symbolic place in a transitory world - lead him to ruminate on questions that undermine such surety: mention of the oracle of the sacred oak tree at Dodona leads him to consider that, given such a chance to discover such truths,

\author{
I would not curious ask \\ The future, best unknown, but at thy mouth \\ Inquisitive, the less ambiguous past. \\ By thee I might correct, erroneous oft, \\ The clock of history
}

(lines 42-6)

This indicates a desire to live outside of the temporal world, and its harmful effects, and to confront only the certainties of the past. The conventional reflection on time and its workings becomes in Cowper's hands a graver deliberation on the mutability that has brought the tree to its ruined state: 'The rottenness which Time is charged to inflict / On other mighty ones found also thee'. Change is portrayed as natural, but destructive, and hardly reassuring:

Change is the diet on which all subsist

Created changeable, and change at last

Destroys them. Skies uncertain, now the heat

Transmitting cloudless, and the solar beam

Now quenching in a boundless sea of clouds,

Calm and alternate storm, moisture and drought,

Invigorate by turns the springs of life

In all that live, plant, animal, and man,

And in conclusion mar them. ${ }^{24}$ 
This depiction of the cycles of nature is not unusual in the movement of a meditative poem, yet the mood created - the stressing, through the syntax of the sentence's ending in destruction and marring - is one of sublime but disturbing grandeur: the fragment of the tree elegized so magnificently, but with such clear emphasis on the inevitability of its being ruined, almost gives the impression of a world without rationale, or controlling force. Some readers, such as Fulford, have found that the poem is a Burkean 'living monument to a shared sense of common ancestry', ${ }^{25}$ but it is also a witness to Cowper's far less communal fears about the changes wrought by history and time, and his inability to exercise any control over them.

A comparison with Clare's 'The Fallen Elm' is suggestive, yet slightly awkward: Cowper's poem was a source, but an extensive parallel between the two founders a little. ${ }^{26}$ Clare bases his poem upon an opposition between the neutral workings of time and the proportionate placing of blame for the tree's destruction upon flawed human motives. Time alters the tree, but does not destroy it:

Old favourite tree thoust seen times changes lower

Though change till now did never injure thee

For time beheld thee as her sacred dower

$\&$ nature claimed thee her domestic tree

Storms came $\&$ shook thee many a weary hour

Yet stedfast to thy home thy roots have been

(lines 15-20; Middle Period, III, 441)

This description may not be as literally accurate as Cowper's delineation of the changes wrought on the oak, but the distinction drawn is clear: it is the arbitrary hand of the owner of the land of the tree who is at fault, not the workings of nature itself. As Clare explained, 'The savage who owns them thinks [the trees] have done their best, and now he wants to make use of the benefits he can get from selling them. ${ }^{127}$ Nature stands outside of (and is implicitly opposed to) greed and self-interest, whereas in Cowper's vision of the old oak change is fused into the workings of worldly forces, so that blame is unspecified. Clare clearly identifies the chopping down of the tree as unnatural, to the point where the poem becomes what Goodridge calls a 'kind of honed political rant $:^{28}$

Thou owned a language by which hearts are stirred

Deeper then by a feeling cloathed in words

$\&$ speakest now whats known of every tongue

Language of pity $\&$ the force of wrong 
The tree is a vessel of protest, rather than a passive repository and record of the necessary evils of change; its symbolic enunciation of what should be felt by all recalls Clare's description in his Autobiography of the unworldly innocence of his friend John Billings: 'he had never read Thomson or Cowper or Wordsworth or perhaps heard of their names yet nature gives everyone a natural simplicity of heart to read her language $\&$ the gross interferences of the world adulterate them'. ${ }^{29}$

The relationship between Clare and Cowper is a microcosm of Clare's use of earlier influence: it is enabling and inspiring, rather than anxious. Clare redefines the terms of the poetic relation to the world and nature in significant ways, particularly in his refusal to accept his marginalization from the social mainstream with the sort of sentimental fatalism that could be fetishized in Cowper. Tim Fulford has recently written sensitively of the detailed ways in which Clare's asylum manuscripts use quotations from him as a lead-in to his own poetry, and thus build upon 'the Cowperian need for refuge into the disclosure of a hidden path, shielded by nature from all but the observant, shared by poet and reader'. ${ }^{30}$ The general aim is the same, but Clare's hidden path is different in degree from Cowper's, in his vision of unalienated pastoral.

This vision is often beleaguered, and represents hidden scenes of inspiration found amidst the apparent mundanity, or even ugliness, of the quotidian in nature, rather than the apparently sublime or overwhelming. 'To the Snipe', one of the most important poems of the Northborough upheaval of spring 1832 , is as far from being a conventional descriptive nature lyric as is possible, choosing a drab, ungainly bird to underscore the spiritual value of the Snipe's marshy environment as an untameable place apart from humanity:

In these thy haunts Ive gleaned habitual love

From the vague world where pride $\&$ folly taunts

I muse $\&$ look above

Thy solitudes

The unbounded heaven esteems

$\&$ here my heart warms into higher moods

$\&$ dignifying dreams

I see the sky

Smile on the meanest spot

Giving to all that creep or walk or flye

A calm \& cordial lot 
John Clare, William Cowper, and the eighteenth century

Thine teaches me

Right feelings to employ

That in the dreariest places peace will be

A dweller \& a joy (lines 73-88; Middle Period, IV, 576-7)

This sense of the divine in nature precisely where it is not expected, in the apparently desolate 'meanest spot', and the related communal feeling of peace as a lasting feeling is meant to convey both the unnatural route of modernity, and its psychic damage to the 'vague world'; here, the specificity of feeling and genuine spiritual replenishment of nature is founded upon an austere Biblical diction: as well as the allusion to Leviticus, there is Clare's debt to the Psalms, traced by Mina Gorji:

the swamp is not portrayed in terms of Bible 'pictures', but it is nonetheless haunted by echoes from the Psalms which transform the landscape beyond the literal. Clare's recognition of a divine order beyond the temporal, natural world and his sense that the snipe could be an emblem of divine protection was a legacy of the Protestant imagination. Clare shared with Cowper and Bunyan, and with Daniel Defoe, a way of seeing visions on the roadside, and of domesticating the visionary into ordinary forms. ${ }^{3 \mathrm{I}}$

This notion of domesticating the visionary, and concomitantly of finding imaginative release and reassurance in a sort of spiritual ecology, is the defining mark of Clare's unique aesthetic. The Protestant imagination too found the impression of divine wonder and purpose in nature and the everyday, but Clare did not just deify that nature, instead setting it apart and against the bourgeois encroachments of modernity, improvement, enclosure, and other imaginatively and spiritually barren modes of thought. This sort of defiance is very different from Cowper's polite complaints, or even Goldsmith's paternalistic vision of pastoral in The Deserted Village, though Clare needed to draw upon such works to create his own ways of defining the significance of place and landscape in an increasingly unsympathetic environment.

Ultimately, it is Clare's sense of renewal and equality in nature, and of the need to place his hope in such renewal, that sets him apart from poets of a Cowperian sensibility. Like many of Clare's late asylum manuscript lyrics, 'O could I be as I have been' seeks to redress intolerance and moral ambiguity - especially as interfering with his understanding of nature through syntactic clarity. It opens with a beseeching, Blakean appeal to childlike simplicity:

O could I be as I have been

And ne'er can be no more 


\section{A harmless thing in meadows green}

Or on the wild sea shore

(lines 1-4; Later Poems, I, 653)

It ends, though, after a list of former pleasures, on a more visionary note:

To gaze upon the starry sky And higher fancies build

And make in solitary joy

Loves temple in the field

(lines 29-32; Later Poems, I, 654)

There is an echo here of Byron's elegiac 'Stanzas for Music' (written in I8I5) which starts 'There's not a joy the world can give like that it takes away', and concludes:

Oh could I feel as I have felt, - or be what I have been,

Or weep as I could once have wept, o'er many a vanished scene:

As springs in deserts found seem sweet, all brackish though they be,

So, midst the wither'd waste of life, those tears would flow to me. ${ }^{32}$

Byron's heartfelt, world-weary elegy may be one source behind Clare's sparse yearning, in plain language, for an uncomplicated return to a world of childish innocence, and instinctive, joyful interaction with nature. It can be noted, though, that even in this he moves away, slightly, from his predecessors: Cowper's last English poem famously concluded with the poet forsaken of all hope, and fearing a worse punishment: 'But I, beneath a rougher sea, / And whelm'd in deeper gulphs than he. ${ }^{33}$ Even at his most isolated, in poetry that seems to will almost an extinction of personality, Clare falls back on the imagination, and 'higher fancies', as well as the spiritual regeneration of nature, with the field as 'loves temple'. It is these sorts of differences in attitude that position him so uniquely within Romanticism, define his relationship with the poetry of the eighteenthcentury, and make him both a natural inheritor of the poetic modes and styles of poets like Thomson and Cowper and immutably different from them, in practice and effect.

\section{Notes}

I. Francis Turner Palgrave, The Golden Treasury of English Songs and Lyrics, ed. Christopher Ricks (Harmondsworth: Penguin, I99I), p. 492.

2. Bridget Keegan, 'Broadsides, Ballads and Books: The Landscape of Cultural Literacy in The Village Minstrel, JCSJ, I5 (I996), II-I9 (II). 
3. Poems Descriptive of Rural Life and Scenery (London: Taylor and Hessey, I820), p. xi. For a suggestive reading of Clare's epiphanic purchase and furtive reading of Thomson, see John Goodridge and Kelsey Thornton, 'John Clare the Trespasser', in Haughton, pp. 87-I29.

4. John Barrell, Poetry, Language, and Politics (Manchester: Manchester University Press, 1988), pp. I00-36 (p. 134).

5. James McKusick, 'Beyond the Visionary Company: John Clare's Resistance to Romanticism', in Haughton, 22I-37, p. 224.

6. James Thomson, The Seasons, ed. James Sambrook (Oxford: Clarendon Press, I98I), p. 2 I4.

7. Paul Chirico, John Clare and the Imagination of the Reader (Basingstoke: Palgrave, 2007), pp. 159, 20. 'Writing Misreading: Clare and the Real World', in The Independent Spirit: John Clare and the Self-Taught Tradition, ed. John Goodridge (Helpston: John Clare Society and Margaret Grainger Memorial Trust, 1994), pp. I25-38 (p. I26).

8. John Goodridge, John Clare and Community (Cambridge: Cambridge University Press, 2013), pp. 36, 37, 58. For his overview of Clare and the eighteenth century, see pp. 36-58.

9. Ibid., pp. 44-5.

IO. For Goodridge's discussion of Pomfret, see pp. 36-40; for Cunningham, pp. 37-46; for Gray, pp. 47-58. Goodridge counters the negative influence of Cunningham perceived by Mark Storey, The Poetry of John Clare (New York: St Martin's, 1974), pp. 37-9. For Clare’s reading, see also Greg Crossan, 'Clare's Debt to the Poets in his Library', JCSJ, Io (I99I), 27-4I.

II. Goodridge, p. 40.

I2. In a more secular age, it is easy to forget that Cowper did not view himself as in any way a professional writer, and that, for various reasons, he lived off other people for most of his adult life. See the useful discussion of Cowper from the innovative perspective of work (or its absence) by Sarah Jordan, in The Anxieties of Idleness (Lewisburg: Bucknell University Press, 2003), pp. 177-216. See James King, William Cowper (Durham, NC: Duke University Press, 1986), pp. 43-5I and 86-94, for outlines of his mental breakdowns.

13. By Himself, p. I35.

I4. 'The Winter Evening' in The Task, Book IV. Poems of William Cowper, ed. John D. Baird and Charles Ryskamp, 3 vols. (Oxford: Clarendon Press, 1995) II, p. 190.

15. Richard Cronin, 'In Place and Out of Place: Clare in the Midsummer Cushion', in New Approaches, pp. 133-48 (p. 136).

16. Clare owned a copy of the Divine Comedy in Henry Cary's hugely influential I8I9 translation, and had met Cary in I820 through mutual London literary connections, and corresponded with him thereafter. See David Powell, Catalogue of the John Clare Collection in the Northampton Public Library (Northampton: Northampton Public Library Collection, 1964), p. 25, no. I5I. Bate, pp. 169, 24I. 
17. The Task, Book V, 'The Winter Morning Walk', The Poems of William Cowper, II, p. $2 \mathrm{I} 2$.

I8. John Milton, Paradise Lost, ed. Alastair Fowler, $2^{\text {nd }}$ edn. (London: Longman, I998), p. I05. The relevant passage is in Book I, lines 739-43:

and in Ausonian land

Men called him Mulciber; and how he fell

From Heaven, they fabled, thrown by angry Jove

Sheer over the crystal battlements: from morn

To noon he fell, from noon to dewy eve,

19. Dated around I840, 'The Gipsy Camp' was one of the poems Clare gave to Cyrus Redding. These twenty poems were published with a supporting essay by Redding in his English Journal, I.20 (I5 May I84I), 305-9 and I.22 (29 May I84I), 340-3.

20. Alan Vardy, John Clare, Politics and Poetry (Basingstoke: Palgrave, 2003), pp. $27,26$.

2I. Tim Fulford, 'Cowper, Wordsworth, Clare: The Politics of Trees', JCSJ, I4 (1995), 47-59 (52-3), quoting from a letter to John Newton, 9 July 1785, The Letters and Prose Writings of William Cowper, ed. James King and Charles Ryskamp, 5 vols. (Oxford: Clarendon Press, 1979-86), II, pp. 362-3.

22. See Poems of William Cowper, II, pp. 317, 316.

23. Ibid., pp. 26-7. I have followed the text of the poem first published in the Gentleman's Magazine in January 1785 , and printed in the footnotes by Baird and Ryskamp, rather than their text based on the manuscript, as the former was the version familiar to readers such as Tennyson, Palgrave, and Clare.

24. Ibid., III, pp. 78, 79-80.

25. Fulford, 'Cowper, Wordsworth, Clare: The Politics of Trees', p. 55.

26. As well as Fulford's mapping of its connections, John Goodridge notes an obvious echo, in passing. John Clare and Community, pp. II6-I7.

27. The Village Minstrel and other Poems (London, I82I), 'Introduction', p. xx.

28. John Clare and Community, p. II8. On Taylor's printing of this letter, and Clare's modifying his view somewhat as the letter progresses ('was People all to feel \& think as I do the world coud not be carried on'), see Sarah M. Zimmerman, Romanticism, Lyricism, and History (Albany: State University of New York Press, 1999), p. I66.

29. The Prose of John Clare, ed. J. W. and Anne Tibble (London, 1970), p. 39.

30. Tim Fulford, 'Personating Poets on the Page: John Clare in his Asylum Notebooks', JCSJ, 32 (2013), 26-48 (32).

31. Mina Gorji, John Clare and the Place of Poetry (Liverpool: Liverpool University Press, 2008), p. II4. For the psalmic in the poem more generally, see pp. I03-I4.

32. George Gordon Lord Byron, The Complete Poetical Works, ed. Jerome McGann, 7 vols. (Oxford: Clarendon Press, 198I), III, pp. 284, 286.

33. 'The Castaway', The Poems of William Cowper, III, p. 216. 